\begin{tabular}{|c|c|c|}
\hline \multirow{3}{*}{$\begin{array}{r}\text { Case Reports in } \\
\text { Gastroenterology }\end{array}$} & \multirow{2}{*}{\multicolumn{2}{|c|}{ Case Rep Gastroenterol 2013;7:392-395 }} \\
\hline & & \\
\hline & $\begin{array}{l}\text { DOI: 10.1159/000355342 } \\
\text { Publisned onlIne: September 9, } 2013\end{array}$ & $\begin{array}{l}\text { (c) } 2013 \text { S. Karger AG, Basel } \\
1662-0631 / 13 / 0073-0392 \$ 38.00 / 0 \\
\text { www.karger.com/crg }\end{array}$ \\
\hline & \multicolumn{2}{|c|}{$\begin{array}{l}\text { This is an Open Access article licensed under the terms of the Creative Commons } \\
\text { Attribution-NonCommercial } 3.0 \text { Unported license (CC BY-NC) (www.karger.com/OA- } \\
\text { license), applicable to the online version of the article only. Distribution permitted for non- } \\
\text { commercial purposes only. }\end{array}$} \\
\hline
\end{tabular}

\title{
Pyloric Gland Adenoma: A Case Report
}

\author{
Ekrem Çakar $^{\mathrm{a}}$ Savaş Bayrak ${ }^{\mathrm{a}}$ Esra Paşaoğlu ${ }^{\mathrm{b}}$ Şükrü Çolak ${ }^{\mathrm{a}}$ \\ Hasan Bektaşa ${ }^{a}$ Ayhan Güneyi ${ }^{a}$ \\ Departments of ${ }^{a}$ General Surgery and ${ }^{b}$ Pathology, Istanbul Training and Research \\ Hospital, Istanbul, Turkey
}

\section{Key Words}

Pyloric glands · Adenoma · Endoscopy

\begin{abstract}
Endoscopic procedures are the gold standard in identifying, monitoring and treating gastrointestinal system lesions. The evaluation of benign, precancerous and malignant characteristics of these lesions requires good endoscopic inspection and precise pathological examination. Pyloric gland adenoma is a rare precancerous lesion defined in recent years and herein is reviewed in the present case along with the literature.
\end{abstract}

(C) 2013 S. Karger AG, Basel

\section{Introduction}

Gastric adenomas are characterized by polypoid appearance of dysplastic epithelium. The frequency of gastric polyps is $7-10 \%$ and they are usually present in two types as foveolar and pyloric gland [1,2]. This neoplasm was defined for the first time by Elster [3] in 1976. In 1990, Watanabe et al. [4] included these lesions in the gastric tumor classification of the World Health Organization. These lesions are frequently located in the mucosa of the gastric corpus [5]. Pyloric gland adenoma has been reported to originate from the duodenum, gallbladder, pancreas, rectum and heterotopic gastric mucosa in Barrett's esophagus as well [6-8]. The aim of the present case report was to recall to health care providers some rare precancerous lesions and to highlight endoscopic and histopathological examination in identifying these lesions. 
Çakar et al.: Pyloric Gland Adenoma: A Case Report

\section{Case Report}

A 60-year-old male patient presented to the gastroenterology clinic due to epigastric pain, heartburn and distension. His anamnesis revealed that these complaints had been present for about a year and that he was on medication due to them. In his medical history, he had only hypertension. His physical examination and laboratory test results were normal. Abdominal ultrasonography was normal as well. Based on these findings, upper gastrointestinal system endoscopy was planned. During endoscopic examination, an approximately 2 $\mathrm{cm}$ polyp with a lobulated surface was detected in the proximal gastric corpus and polypectomy was performed. Microscopic examination revealed a polyp consisted of glands, some of which presented cystic dilatation, and arranged back-to-back under gastric foveolar epithelium that covered the surface. On immunohistochemical examination, while MUC 5AC was positive in the gastric foveolar epithelium that covered the surface of the polyp and was negative in glandular structures, MUC 6 was found to be positive in the glands and negative on the surface of the polyp (fig. 1, fig. 2). Since the morphological appearance of the glands and the immunohistochemical MUC 6 positivity were consistent with pyloric glands, the lesion was reported as 'pyloric gland adenoma'. A gland that was covered with cells having hyperchromatic nuclei and presented pseudostratification in a focal area inside the polyp attracted attention. This area was considered as high-degree dysplasia since hyperchromatic nuclei had reached up to cell surface (fig. 3).

\section{Discussion}

Pyloric gland adenoma is a rare tumor of the gastric mucosa. Since data about these tumors are lacking, it is frequently not diagnosed or reported as dysplasia. During endoscopic examination, pyloric gland adenoma is often observed as a 'dome-like' lesion [6]. This rare tumor is characterized by thick pyloric gland tubules confined by cuboidal epithelial cells with pale, eosinophilic cytoplasm [2]. The nucleus of these cells is round or ovoid and may have a small or no nucleolus. These tumors are closely associated with MUC 6 and MUC 2 . MUC 6 is a pyloric gland marker and is often found deep in the lesion, whereas MUC 5AC is found on the surface of the lesion [5, 7, 9]. A number of chromosomal anomalies have been associated with these tumors. Kushima et al. [7] reported these anomalies. This tumor has been associated with metaplasia and autoimmunity; nevertheless, additional studies are needed for both pathophysiology of the disease and its relation with other diseases. Vieth et al. [10] investigated 2,778 cases diagnosed with gastric polyp between 1990 and 2000 to obtain more clinical data from patients having this rare lesion and reported 90 of these lesions as pyloric gland adenoma, of which 77 were in the stomach, 7 in the bulbus, 1 in the duodenum, 3 in the bile duct and 2 in the gallbladder. Pyloric gland adenoma accounted for $2.7 \%$ of all gastric polyps and was mostly observed in females aged $73 \pm 12.8$ years. The female:male ratio was reported to be 3:1. The rate of the lesion in the mucosa of the gastric corpus was found to be $64 \%$. Autoimmune gastritis was detected in $36 \%$ of patients. The mean size of pyloric gland adenoma was found to be $16.1 \pm 9.1 \mathrm{~mm}$ at the time of diagnosis. It was detected that the tumor changed into well-differentiated adenocarcinoma in 30\% of these cases. The study reported pyloric gland adenoma as the third leading tumor among gastric neoplastic polypoid lesions even though it is a rare lesion among gastric polyps [10].

Pyloric gland adenomas are precancerous lesions presenting a high probability of change into gastric adenocarcinoma and having indications of endoscopic polypectomy. Pathologists and endoscopists need to be extremely alert about these types of lesions during routine examination. 


\begin{tabular}{l|l}
\hline \multicolumn{2}{l}{ Case Rep Gastroenterol 2013;7:392-395 } \\
\hline DOI: 10.1159/000355342 & $\begin{array}{l}\text { C 2013 S. Karger AG, Basel } \\
\text { www.karger.com/crg }\end{array}$ \\
\hline
\end{tabular}

Çakar et al.: Pyloric Gland Adenoma: A Case Report

\section{Disclosure Statement}

The authors disclose no conflict of interest.

\section{References}

1 Abraham SC, Montgomery EA, Singh VK, Yardley JH, Wu TT: Gastric adenomas: intestinal-type and gastrictype adenomas differ in the risk of adenocarcinoma and presence of background mucosal pathology. Am J Surg Pathol 2002;26:1276-1285.

2 Kushima R, Mukaisho K, Vieth M, Borchard F, Stolte M, Hattori T: Pyloric-gland-type adenomas of the stomach (in Japanese). Stomach Intestine 2003;38:1377-1387.

3 Elster K: Histologic classification of gastric polyps; in Morson BC (ed): Pathology of the Gastro-Intestinal Tract. Berlin, Springer, 1976, pp 78-92.

4 Watanabe H, Jass JR, Sobin LH: Histological Typing of Oesophageal and Gastric Tumours. Berlin, Springer, 1990.

5 Kushima R, Vieth M, Borchard F, Stolte M, Mukaisho K, Hattori T: Gastric-type well-differentiated adenocarcinoma and pyloric gland adenoma of the stomach. Gastric Cancer 2006;9:177-184.

6 Takei K, Watanabe H, Itoi T, Saito T: p53 and Ki-67 immunoreactivity and nuclear morphometry of 'carcinoma-in-adenoma' and adenoma of the gall-bladder. Pathol Int 1996;46:908-917.

7 Kushima R, Vieth M, Mukaisho K, Sakai R, Okabe H, Hattori T, Neuhaus H, Borchard F, Stolte M: Pyloric gland adenoma arising in Barrett's esophagus with mucin immunohistochemical and molecular cytogenetic evaluation. Virchows Arch 2005;446:537-541.

8 Kato N, Akiyama S, Motoyama T: Pyloric gland-type tubular adenoma superimposed on intraductal papillary mucinous tumor of the pancreas. Pyloric gland adenoma of the pancreas. Virchows Arch 2002;440:205-208.

$\checkmark 9$ Chen ZM, Scudiere JR, Abraham SC, Montgomery E: Pyloric gland adenoma: an entity distinct from gastric foveolar type adenoma. Am J Surg Pathol 2009;33:186-193.

10 Vieth M, Kushima R, Borchard F, Stolte M: Pyloric gland adenoma: a clinico-pathological analysis of 90 cases. Virchows Arch 2003;442:317-321.

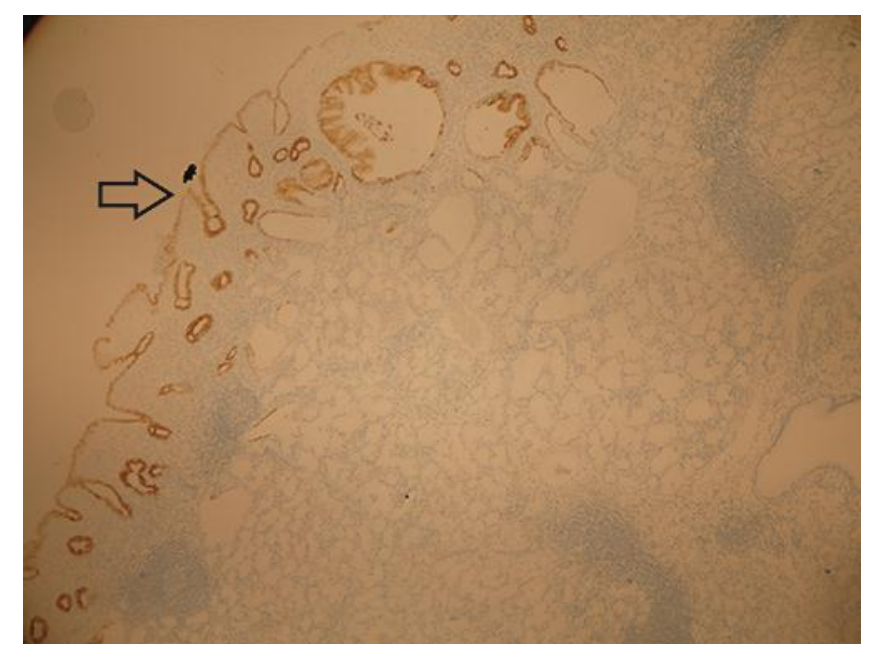

Fig. 1. MUC 5AC was positive in the gastric foveolar epithelium of the surface (arrow). Immunostaining was not observed in the pyloric glands. $\times 100$. 
Çakar et al:: Pyloric Gland Adenoma: A Case Report

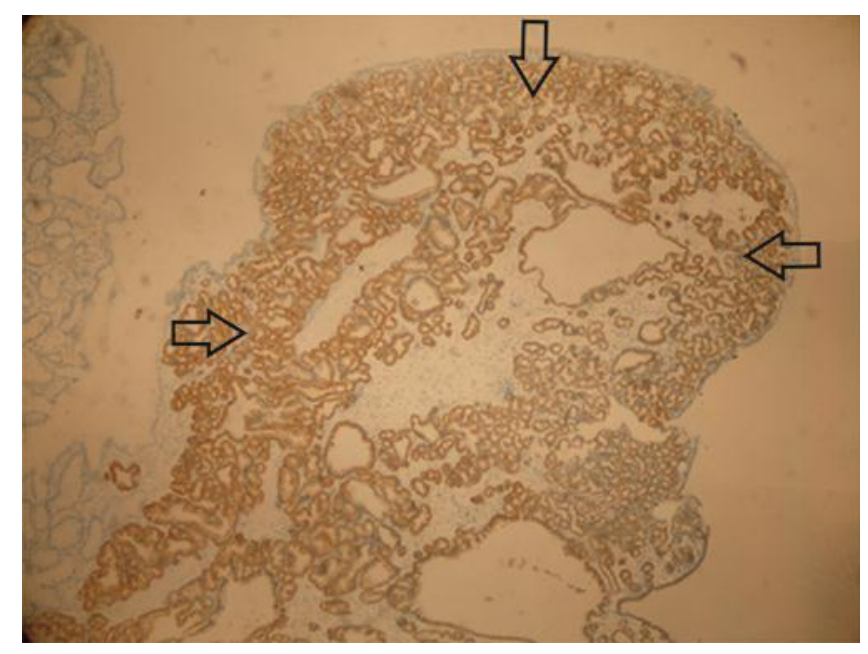

Fig. 2. MUC 6 positivity in the pyloric glands that formed the lesion (arrows). $\times 40$.

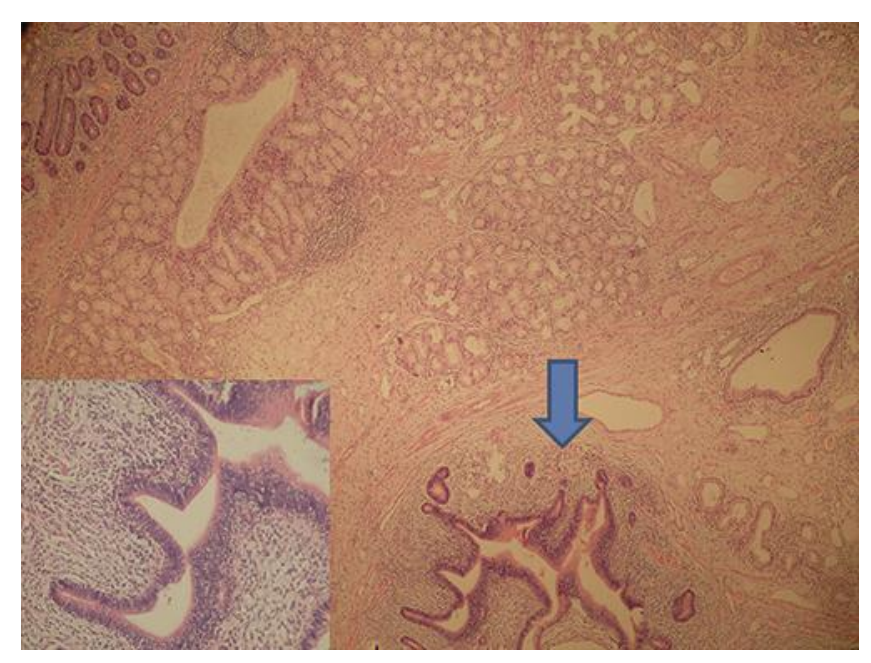

Fig. 3. A glandular structure that was covered with cells having hyperchromatic nuclei in a focal area attracted attention. The cigar-shaped hyperchromatic nuclei that presented pseudostratification were considered as high-degree dysplasia since they reached up to cellular surface (arrow). H\&E, $\times 40$. 